\title{
The evaluation of relation between vitamin B12 and body mass index
}

\author{
Eray Atalay $^{1} \odot$, Nurullah Aslan² ${ }^{2}$, Pınar Şişman $^{3} \odot$ \\ ${ }^{1}$ Department of Internal Medicine, Kafkas University of School of Medicine, Kars, Turkey \\ ${ }^{2}$ Department of Internal Medicine, Siverek State Hospitak, Şanluurfa, Turkey \\ ${ }^{3}$ Department of Endocrinology and Metabolism, Bursa Medicana Hospital, Bursa, Turkey
}

\begin{abstract}
Objectives: Obesity has become a pandemy all around the world, etiology of obesity consist multiple factors and it causes serious health problems. It is known that the low level of vitamin B12 has adverse effects on many systems, mainly cell DNA. In our study, it was planned to evaluate whether there is a relation between body mass index and serum vitamin B12 level.

Methods: We included 168 patients aged 18-67 years, who did not have a chronic disease and who applied to the outpatient clinic in our center. We divided the patients into 3 groups according to the body mass index (BMI): Group I: normal weight (BMI: 18.50-24.99 kg/m2); Group II: overweight (BMI: $25-29.9 \mathrm{~kg} / \mathrm{m}^{2}$ ) and Group III: obese (BMI: $\left.\geq 30 \mathrm{~kg} / \mathrm{m}^{2}\right)$. Vitamin B12 levels were evaluated between these groups.

Results: There was a statistically significant difference between the groups in terms of glucose, total cholesterol, HDL-cholesterol, LDL-cholesterol and triglyceride. Vitamin D levels were not statistically significant between the groups. The mean serum vitamin B12 levels of the individuals were $299 \pm 125 \mathrm{pmol} / \mathrm{L}$, $298 \pm 148 \mathrm{pmol} / \mathrm{L}$ and $313 \pm 143 \mathrm{pmol} / \mathrm{L}$ in Group I, Group II and Group III, respectively. There was no statistically significant difference and correlation between BMI and serum vitamin B12 levels in the groups. Conclusions: The etiology of obesity, a serious health problem in today's society, has proven to be multifactorial. No significant association was found between BMI and vitamin B12 levels at the end of the study. It was concluded that similar studies should be performed with a large case series.

Keywords: vitamin B12, cobalamin, obesity, body mass index
\end{abstract}

$\mathrm{O}$ besity, which is one of the most important health problems of the developed and developing countries in the world today, is a chronic energy metabolism disorder which is caused by excess fat accumulation in the body and can cause physical and mental problems [1]. Obesity is a complex disease involving appetite regulation and energy metabolism, not a simple eating problem due to lack of autocontrol [2]. Psychological, hormonal, metabolic disorders and pharmacological factors play a role in the formation of obesity, as well as various environmental factors that trigger genetic predisposition and impaired energy balance [3].

The endocrine, cardiovascular, respiratory, gastrointestinal, genitourinary and musculoskeletal system and skin, as well as psychosocial state are affected obesity at varying rates. In addition, studies have shown that obesity leads to various diseases such as 
malignancy (breast, over and endometrium in women, colon and prostate in men), gout, stroke and depression [4]. Many methods of measurement are used in the evaluation of obesity. Among these, the body mass index (BMI), which is practical in clinical practice, was first described by Quetelet in 1835 and is now the most commonly used method [5].

Vitamin B12 acts as an important coenzyme and cofactor in the synthesis of deoxyribonucleic acid (DNA) and is necessary for the maintenance of normal hematopoiesis and for the continuity of the nervous system [6]. Clinical findings are rare in vitamin B12 deficiency; however, hematologic, neuropsychiatric and gastrointestinal signs and symptoms are most frequently seen [7]. The prevalence of vitamin B12 deficiency in the whole population is not fully understood but it is known that the incidence of vitamin B12 deficiency increases with age. It is frequently seen in about $10-15 \%$ over the age of $60[8,9]$.

Many studies have shown that the etiology of obesity, a public health problem on a global scale, is multifactorial. It is known that the low level of vitamin B12 has adverse effects on many systems, mainly cell DNA. In our study, it was planned to evaluate whether there is a relation between body mass index and serum vitamin B12 level.

\section{METHODS}

We included 168 patients aged 18-67 years, who did not have a chronic disease and who applied to the outpatient clinic in our center from January 2015 to December 2016. Exclusion criterias were rheumatoid arthritis, ankylosing spondylitis, collagen tissue disease, celiac, hypo-hyperthyroidism, hematologic disease, malignancy, leukemia, lymphoma, malnutrition, malabsorption, and active infection. We also excluded patients previously treated with vitamin B12 and immunsuppressive drug. Written consent of the study participants, and ethics committee approval from our center were obtained. We divided the patients into 3 groups according to the BMI: Group I: normal weight (BMI: 18,50-24,99 $\mathrm{kg} / \mathrm{m}^{2}$ ); Group II: overweight (BMI: $25-29.9 \mathrm{~kg} / \mathrm{m}^{2}$ ) and Group III: obese (BMI: $\geq 30 \mathrm{kgm}^{2}$ ).

Complete blood counts were obtained with tubes containing ethylenediaminetetraacetic acid (EDTA) and examined with the Bt pro 2401 instrument. Biochemical measurements were determined by using a biochemical analyzer for serum glucose and lipid panel Cobas 6000 C501 (Roche Diagnostics GmbH, Mannheim, Germany) in blood samples taken after at least 12-14 hours of fasting. Serum vitamin D and vitamin B12 levels were determined by the Cobas e 411 (Roche Diagnostics GmbH, Mannheim, Germany) analyzer. The normal range of serum vitamin B12 was accepted as 200-800 pg/mL.

The height and weight of the subjects were measured to calculate BMI. Weight of the subjects was measured in the upright position after 12-14 hours of fasting. Height measurement of the subjects was made by measuring the distance from the head to the base, ensuring that the subjects were standing upright, with their feet naked and adjacent.BMI was calculated based as weight in kilograms divided by the square of the height in metres $\left(\mathrm{kg} / \mathrm{m}^{2}\right)$.

\section{Statistical Analysis}

Statistical analyzes were performed using the SPSS 24.0 program (SPSS Inc. Chicago, IL). The normal distribution of the variables was tested by Kolmogorov smirnov and the variance equation by the Levene test. All analyzes were performed by parametric tests, since the data were normally distributed. Continuous variables were expressed as mean \pm standard deviation, and categorical variables as percent.Independent-Samples T-Test for numerical variables and Chi square test for categorical variables were used to compare group averages. The relationship between BMI and biochemical parameters was assessed by Pearson correlation analysis. Parameters that were statistically significant in binary comparisons were included in the multivariate model. The results were evaluated in a confidence interval of $95 \%$ and a significance level of $p<0.05$.

\section{RESULTS}

Of the 168 individuals included in the study, 125 (66.1\%) were females and 43 (33.9\%) were males. The average age is $37.6 \pm 8.8$ years. In all the subjects studied, the mean height was $166.0 \pm 8 \mathrm{~cm}$ and the mean BMI was $27 \pm 6.5 \mathrm{~kg} / \mathrm{m} 2$. The patients were divided into 3 groups according to the BMI and 77 
Table 1. Comparison of age, height, weight and BMI of groups

\begin{tabular}{lcccc}
\hline Variables & $\begin{array}{c}\text { Group I } \\
(\mathbf{n}=\mathbf{7 7})\end{array}$ & $\begin{array}{c}\text { Group II } \\
(\mathbf{n}=\mathbf{3 5})\end{array}$ & $\begin{array}{c}\text { Group III } \\
(\mathbf{n}=\mathbf{5 6})\end{array}$ & $\boldsymbol{p}$ value \\
\hline Age $($ year $)$ & $27 \pm 10$ & $40 \pm 12$ & $46 \pm 11$ & $<\mathbf{0 , 0 0 1}$ \\
Height $(\mathrm{cm})$ & $164 \pm 7$ & $168 \pm 8$ & $164 \pm 8$ & $\mathbf{0 . 0 3 4}$ \\
\hline Weight $(\mathrm{kg})$ & $57 \pm 8$ & $78 \pm 8$ & $94 \pm 17$ & $<\mathbf{0 . 0 0 1}$ \\
BMI $\left(\mathrm{kg} / \mathrm{m}^{2}\right)$ & $21 \pm 2$ & $28 \pm 2$ & $35 \pm 5$ & $<\mathbf{0 . 0 0 1}$ \\
\hline
\end{tabular}

patients, 35 patients and 56 patients were included in to the Group I (normal weight), Group II (overweight) and Group III (obese), respectively. When the cases grouped according to BMI were examined according to age; the mean age of the individuals in Group I was $27 \pm 10$ years, the mean age of individuals in Group II was $40 \pm 12$ years and the mean age of individuals in Group III was $46 \pm 11$ years. There was a statistically significant difference in age between groups $(p<$ 0.001) (Table 1).

When the groups were examined according to the serum glucose levels, the mean serum glucose level of the individuals was $90 \pm 8 \mathrm{mg} / \mathrm{dL}, 96 \pm 10 \mathrm{mg} / \mathrm{dL}$, and $103 \pm 14 \mathrm{mg} / \mathrm{dL}$ in Group I, Group II and Group III, respectively. There was a statistically significant difference between the groups in terms of serum glucose level $(p<0.001)$ (Table 2).

When the groups were examined according to the mean serum total cholesterol level, mean total cholesterol levels were $162 \pm 32 \mathrm{mg} / \mathrm{dL}$ in Group I, $193 \pm 45 \mathrm{mg} / \mathrm{dL}$ in Group II and $195 \pm 43 \mathrm{mg} / \mathrm{dL}$ in Group III. Mean serum LDL-cholesterol levels; $93 \pm$ $24 \mathrm{mg} / \mathrm{dL}$ in Group I, $120 \pm 36 \mathrm{mg} / \mathrm{dL}$ in Group II and $122 \pm 37 \mathrm{mg} / \mathrm{dL}$ in Group III. When the groups were examined according to the mean HDL-Cholesterol level, mean HDL cholesterol levels were detected 54 $\pm 12 \mathrm{mg} / \mathrm{dL}$ in group I, $48 \pm 13 \mathrm{mg} / \mathrm{dL}$ in group II and $46 \pm 12 \mathrm{mg} / \mathrm{dL}$ in group III. Mean serum triglyceride levels were $81 \pm 30 \mathrm{mg} / \mathrm{dL}$ in Group I, $135 \pm 97 \mathrm{mg} / \mathrm{dL}$ in Group II and $138 \pm 68 \mathrm{mg} / \mathrm{dL}$ in Group III.There was a statistically significant difference between the groups in terms of total cholesterol, HDL-cholesterol, LDL-cholesterol and triglyceride $(p<0.001)$ (Table 2).

When the serum vitamin D levels of the groups were examined, the mean serum vitamin $\mathrm{D}$ level of the individuals was $12 \pm 11 \mathrm{ng} / \mathrm{mL}, 13 \pm 5 \mathrm{ng} / \mathrm{mL}$ and 13 $\pm 7 \mathrm{ng} / \mathrm{mL}$ in Group I, Group II and Group III,

Table 2. Comparison of glucose and lipid levels of groups

\begin{tabular}{lcccc}
\hline Parameters & $\begin{array}{c}\text { GROUP I } \\
(\mathbf{n}=\mathbf{7 7})\end{array}$ & $\begin{array}{c}\text { GROUP II } \\
(\mathbf{n}=\mathbf{3 5})\end{array}$ & $\begin{array}{c}\text { GROUP III } \\
(\mathbf{n = 5 6 )}\end{array}$ & $\boldsymbol{p}$ value \\
\hline Glucose $(\mathrm{mg} / \mathrm{dL})$ & $90 \pm 8$ & $96 \pm 10$ & $103 \pm 14$ & $<\mathbf{0 . 0 0 1}$ \\
Total Cholesterol (mg/dL) & $162 \pm 32$ & $193 \pm 45$ & $195 \pm 43$ & $<\mathbf{0 . 0 0 1}$ \\
\hline LDL-Cholesterol (mg/dL) & $93 \pm 24$ & $120 \pm 36$ & $122 \pm 37$ & $<\mathbf{0 . 0 0 1}$ \\
HDL-Cholesterol (mg/dL) & $54 \pm 12$ & $48 \pm 13$ & $46 \pm 12$ & $<\mathbf{0 . 0 0 1}$ \\
Triglyceride (mg/dL) & $81 \pm 30$ & $135 \pm 97$ & $138 \pm 68$ & $<\mathbf{0 . 0 0 1}$ \\
\hline
\end{tabular}

Table 3. Comparison of serum vitamin D levels in groups

\begin{tabular}{lcccc}
\hline Variables & $\begin{array}{c}\text { Group I } \\
(\mathbf{n}=\mathbf{7 7})\end{array}$ & $\begin{array}{c}\text { Group II } \\
(\mathbf{n}=\mathbf{3 5})\end{array}$ & $\begin{array}{c}\text { Group III } \\
(\mathbf{n}=\mathbf{5 6})\end{array}$ & $\boldsymbol{p}$ value \\
\hline BMI $\left(\mathrm{kg} / \mathrm{m}^{2}\right)$ & $21 \pm 2$ & $28 \pm 2$ & $35 \pm 5$ & 0.750 \\
\hline Vitamin D $(\mathrm{ng} / \mathrm{mL})$ & $12 \pm 11$ & $13 \pm 5$ & $13 \pm 7$ & \\
\hline
\end{tabular}


Table 4. Comparison of serum vitamin B12 levels in groups

\begin{tabular}{lccccc}
\hline Variables & $\begin{array}{c}\text { Group I } \\
(\mathbf{n}=\mathbf{7 7})\end{array}$ & $\begin{array}{c}\text { Group II } \\
(\mathbf{n}=\mathbf{3 5})\end{array}$ & $\begin{array}{c}\text { Group III } \\
(\mathbf{n}=\mathbf{5 6})\end{array}$ & $\boldsymbol{p}$ values & r values \\
\hline BMI $\left(\mathrm{kg} / \mathrm{m}^{2}\right)$ & $21 \pm 2$ & $28 \pm 2$ & $35 \pm 5$ & 0.430 & 0.014 \\
\hline Vitamin B12 $(\mathrm{pmol} / \mathrm{L})$ & $299 \pm 125$ & $298 \pm 148$ & $313 \pm 143$ & & \\
\hline
\end{tabular}

respectively. There was no statistically significant difference in serum vitamin $\mathrm{D}$ levels between the groups $(p=0.750)$ (Table 3$)$.

The mean serum vitamin B12 levels of the individuals in Group I were $299 \pm 125 \mathrm{pmol} / \mathrm{L}$, the mean serum vitamin B12 levels of the individuals in Group II were $298 \pm 148 \mathrm{pmol} / \mathrm{L}$ and the mean serum vitamin B12 levels of the individuals in Group III were $313 \pm 143 \mathrm{pmol} / \mathrm{L}$. There was no statistically significant difference and correlation between BMI and serum vitamin B12 levels in the groups $(p=0.430$, $\mathrm{R}=0.014$ ) (Table 4) (Fig. 1).

\section{DISCUSSION}

Obesity is a multifactorial and complex disease that is the result of interaction of genetic and environmental factors [10]. The main risk factors for obesity development are; decreased physical activity, wrong eating habits, increasing age, being female, number of births, marriage, smoking and alcohol intake. Reasons for the progressive increase in obesity, a decrease in activity due to sedanter's lifestyle and an increase in fast food-style eating habits and excessive calorie intake [3].

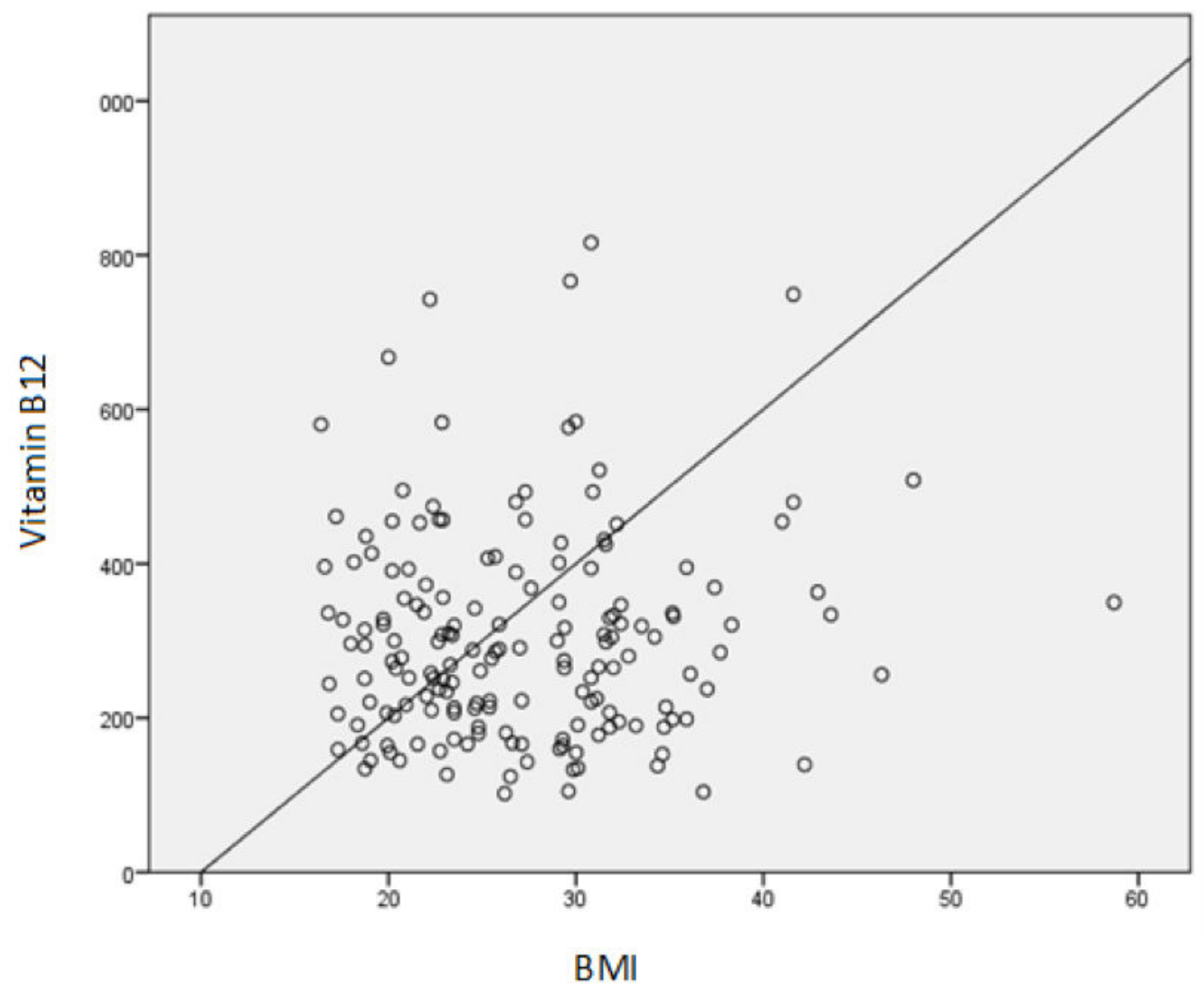

Fig. 1. Correlation of BMI and serum vitamin B12 levels. 
In some studies evaluating the relation of obesity with age, an increase in obesity was observed with increasing age [11]. In a study conducted by Lagunova et al. [12], in which 2126 subjects were included, a significant relationship was found between BMI and age. In another study conducted by Akman et al. [13], it was observed that the prevalence of obesity increased in parallel with the increase in age up to the age of 60 . Similar to these studies, there was a statistically significant difference between the groups in terms of the age groups grouped according to BMI $(p<0.001)$.

Many studies have shown that abdominal fat tissue accumulation, an indicator of obesity, is associated with atherogenic and diabetic disorders such as insulin resistance, hyperinsulinemia, glucose intolerance, dyslipoproteinemia, and hypertension. The relative risk of diabetes mellitus increases up to $60.9 \%$ when BMI exceeds $35 \mathrm{~kg} / \mathrm{m}^{2}$ [14]. It is thought that the duration of obesity and its type, that is, central type fat accumulation, is more effective in the development of diabetes mellitus and glucose intolerance than the degree of obesity $[15,16]$. A study conducted by Kutlutürk et al. [17] investigated the relationship between obesity and metabolic risk factors and found a significant relationship between obesity and fasting serum glucose levels. Innocent et al. [18] found a positive but weak correlation between BMI and serum glucose level in their studies. Similar to these studies, in our study, there was a statistically significant difference in serum glucose levels between the subjects grouped according to BMI $(p<0.001)$.

Obesity causes adverse changes in lipid metabolism. These include high total cholesterol, LDL-cholesterol, VLDL-cholesterol, triglyceride levels and low HDL-cholesterol.HDL-cholesterol levels were 5\% lower in obese subjects [19]. In general, in obese subjects, fasting plasma triglyceride values tend to increase and plasma HDL-cholesterol levels tend to decrease [20]. In a study conducted by Faheem et al. [21], a total of 2,270 patients were included in the study, and a positive correlation was found between the BMI and cholesterol parameters. In our study, when the cases were grouped according to BMI, there was a negative correlation between BMI and total cholesterol, LDL-cholesterol and triglyceride, and a negative correlation between BMI and HDL-cholesterol.
Low vitamin D levels have been demonstrated in many studies involving obesity, diabetes mellitus, and the metabolic syndrome. This relationship is explained by the demonstration of vitamin $\mathrm{D}$ receptor) (VDR) expression in fat tissue, the solubility of vitamin $\mathrm{D}$ in fat and its storage in fat tissue. However, vitamin D has been shown to play a role in the modulation of insulin production and secretion in animal studies, with a negative correlation between BMI and vitamin D levels. Active vitamin $D$ has been shown to stimulate calcium exchange in pancreatic $\beta$ cells and mouse models in vitro. There is strong evidence that vitamin $\mathrm{D}$ affects the release of insulin from $\beta$-cells of the pancreas, and that active vitamin $D$ inhibits lipolysis and exhances lipogenesis by inhibiting uncoupling protein-2 protein in fat cells. In mice without VDR, it was reported that all fat mass decreased, serum leptin level decreased and energy consumption increased [22, 23].

There are, however, studies suggesting that there is no significant relationship between vitamin D levels and obesity. In Gronborg et al.'s study [24], it was observed that there was basically no relation between vitamin $\mathrm{D}$ level and body fat ratio, and body fat ratio did not respond to vitamin D supplementation. In our study, there was no statistically significant difference in serum vitamin D levels between the cases grouped according to BMI ( $p=0.750)$. All of the groups in our study had vitamin D deficiency.It is thought that vitamin D deficiency in all groups is due to the fact that the geographical region where we are studying is high altitude, heavy winter climate, low sun light due to climate conditions and low exposure sunlight due to clothing style.

Vitamin B12, which plays a vital role in the functioning of many important molecules and hormones, especially in the production of DNA, which is essential for cell division and proliferation, is an important essential vitamin. It can not be synthesized in the human body and is abundant in proteins, especially those derived from animal origin. Approximately 6 micrograms per day should be taken [7]. It can be stored in small quantities in the body, $80 \%$ of which occurs in the liver. In the case of deficiency, it takes 3-4 years for clinical signs to appear in case of deficiency [25].

The prevalence of vitamin B12 deficiency in the world is not known precisely. However, it is generally 
known that the incidence increases with age. In one study, vitamin B12 deficiency was detected in about $15 \%$ of people over 65 years of age.In general, the incidence of vitamin B12 deficiency in adults is 5-20\% on average $[8,26,27]$. In a surveillance study in the United States; when the basal level of vitamin B12 was taken as $148 \mathrm{pmol} / \mathrm{L}$, vitamin B12 deficiency was found in 3\% between $20-39$ years, $4 \%$ between $40-59$ years and $6 \%$ over 60 years. In another study, vitamin B12 deficiency was found to be $14-16 \%$ between 20 59 years and $20 \%$ over 60 years when taking 221 $\mathrm{pmol} / \mathrm{L}[28,29]$.

Vitamin B12 is a cofactor in methionine synthesis from homocysteine [30]. Deficiency of vitamin B12 causes hyperhomocystinemia. Cohort studies have shown that even mild hyperhomocystinemia increases cardiovascular morbidity and mortality [31, 32]. Martos et al. [33] found that hyperhomocystinemine correlates with insulin resistance in obese prepubertal children [33]. Güven et al. [34] found low levels of vitamin B12 in patients with adult metabolic syndrome compared to normal healthy individuals. In another study, it was shown that homocysteine levels returned to normal range with folate and vitamin B12 treatment in patients with metabolic syndrome with low serum folate and serum vitamin B12 levels. It has been found that it has a positive effect on the recovery of insulin resistance and contributes to the regression of endothelial dysfunction [35].

In the study performed by Baltaci et al. [36], 680 female subjects aged 18-68 years were divided into two groups as obese and normal weight according to BMI and serum vitamin B12 level was found to be low in the group with high BMI. In this study, it was suggested that in obese individuals, vitamin B12 deficiency is independent of nutritional status. In the same study, there was no correlation between serum vitamin B12 levels and insulin resistance and visceral obesity [36]. In a study conducted by Ho et al. [37], a significant portion of obese adolescents bearing the risk of type 2 diabetes mellitus were found to have low or borderline serum vitamin B12. In addition, negative correlations were found between serum vitamin B12 levels and BMI in this study [37]. In a study conducted by Goyal et al. [38], authors reported that serum vitamin B12 deficiency was more common in the morbidly obese population. In another study, 995 women who were on the 28th week of their gestation were included to the study and a $0.6 \%$ decrease in serum vitamin B12 was detected for every $1 \%$ increase in BMI. However, the differences in socioeconomic status, the presence of vitamin supplements or vegetarian diet-style nutrition, the number of parities and the lack of full exclusion of hemodilution due to pregnancy were the the limitation of the study [39].

In a study, 228 normal weight and 164 obese participants included to the study and serum vitamin B12 levels were found to be low in $10.4 \%$ of the obese participants and only $2.2 \%$ of the participants with normal weight [40]. The authors explained that the reason for this that the nutritional content of obese individuals is low in terms of vitamin B12 despite being rich in terms of carbohydrate and fat [40]. In another study, serum vitamin B12 levels were examined in adolescents between 10 and 17 years of age with clinical features of pre-diabetes and/or insulin resistance [41]. In adolescents with serum vitamin B12 level $\leq 221 \mathrm{pmol} / \mathrm{L}$, BMI was higher and gender difference was not observed. It was emphasized that this low level was caused by low vitamin B12 in the nutritional content [41]. Vitamin B12 plays an important role in DNA methylation. Recent genomic analysis has suggested that increased DNA methylation is associated with increased BMI in adults [42].

On the other hand, in a study involving Brazilian overweight adolescents, serum vitamin B12 concentrations were compared with BMI and no significant difference was found [43]. In the study conducted by Reitman et al. [44], there was no statistically significant difference in the levels of serum vitamin B12 in patients overweight and obese compared to those in normal weight. Abu-Samak et al. [45] found that the mean serum vitamin B12 level was low in overweight $\left(\mathrm{BMI}=25-29.9 \mathrm{~kg} / \mathrm{m}^{2}\right)$, but there was no decrease in vitamin B12 levels in obese $\left(\mathrm{BMI} \geq 30 \mathrm{~kg} / \mathrm{m}^{2}\right)$. El-Quadah et al. [46] observed that serum vitamin B12 levels increased as the BMI increased for the subjects included in the study.

In our study, when the serum vitamin B12 levels of the cases grouped according to BMI were examined, serum vitamin B12 levels of the individuals in Group I were $299 \pm 125 \mathrm{pmol} / \mathrm{L}$, serum vitamin B12 levels of the individuals in Group II were $298 \pm 148$ $\mathrm{pmol} / \mathrm{L}$ serum vitamin B12 levels of the individuals 
were $313 \pm 143 \mathrm{pmol} / \mathrm{L}$. There was no statistically significant difference in serum vitamin B12 levels between the groups. Statistical analysis of serum vitamin $\mathrm{B} 12$ and $\mathrm{BMI}$ did not reveal significant association $(p=0.430, \mathrm{R}=0.014)$.

\section{CONCLUSION}

As a result, the etiology of obesity, a serious health problem in today's society, has proven to be multifactorial. In this study, we also investigated whether there is a relationship between vitamin B12 and obesity. However, the retrospective nature of our study and the inclusion of only a small cross-sectional group were among the limitations of this study. No significant association was found between VKI and vitamin B12 levels at the end of the study. It was concluded that similar studies should be performed with a large case series.

\section{Conflict of interest}

The authors disclosed no conflict of interest during the preparation or publication of this manuscript.

\section{Financing}

The authors disclosed that they did not receive any grant during conduction or writing of this study.

\section{REFERENCES}

1. WHO. Obesity: Preventing and Managing the Global Epidemic. WHO Technical Report Series http://www.who.int/nutrition/publications/obesity/

WHO TRS 894/en.

2. Serter R. Obezite Atlası. 1. Bask1, Ankara: Karakter Color, 2004.

3. Başkal N. Obezite. İn: Erdoğan G. ed., Klinik Endokrinoloji, Ankara: Antıp AŞ, 2003:325-53.

4. Sidorov JE, Fitzner K. Obesity disease management opportunities and barriers. Obesity 2006;14:45-54.

5. Després JP. Dyslipidemia and obesity. Baillieres Clin Endocrinol Metab 1994;8.629-60.

6. Soysal T. Megaloblastik Anemiler. İ.Ü. Cerrahpaşa Tıp Fakültesi Sürekli Tıp Eğitimi Etkinlikleri. Anemiler Sempozyumu. İstanbul, 2001:33-47.

7. Oh RC, Brown DL. Vitamin B12 deficiency. Am Fam Physician 2003;67:979-86.

8. Wolters M, Ströhle A, Hahn A. Cobalamin: a critical vitamin in the elderly. Prev Med 2004;39:1256-66.

9. Dankı D, Telci Ş, Dilbaz N, Okay IT. [Psychotic disorder due to vitamine B12 defiency]. Klinik Psikofarmakoloji Bülteni 2006;16:109-13. [Article in Turkish]

10. Taşan E. [Identification, evaluation and epidemiology of obesity]. Turkiye Klinikleri J Int Med Sci 2005;1:1-4. [Article in Turkish]

11. Akbay E, Buğdaycı R, Tezcan H, Konca K, Yazar A, Pata C. The prevalence of obesity in adult population in a city on the Mediterranean coast of Turkey. Turkish J Endocrinol Metab 2003;7:31-5.

12. Lagunova Z, Porojnicu AC, Lindberg F, Hexeberg S, Moan $\mathrm{J}$. The dendency of vitamin d status on body mass index, gender, age and season. Anticancer Res 2019;29:3713-20.

13. Akman M, Budak Ş, Kendir M. [Obesity and related health problems: an adult outpatient clinical setting]. Marmara Med J 2004;17;113-20. [Article in Turkish]

14. Colditz GA, Willet C, Rotnitzky A. Weight gain as a risk factor for clinical diabetes mellitus in women. Ann Intern Med 1995;122:481-6.

15. McKeigue PM, Pierpoint T, Ferrie JE, Marmot MG. Relationship of glucose intolerance and hyperinsulinemia to body fat patern in South Asians and Europeans. Diabetologia 1992;35:785-91.

16. Pouliot MC, Després JP, Nadeau A, Moorjani S, Prud'Homme $\mathrm{D}$, Lupien PJ, et al. Visceral obesity in men. Associations with glucose tolerance, plasma insulin and lipoprotein levels. Diabetes 1992;41:826-34.

17. Kutlutürk F, Öztürk B, Yıldırım B, Özuğurlu F, Çetin İ, Etikan $\dot{I}$, et al. [Obesity prevalence and its association with metabolic risk factors: Tokat province prevalence study]. Turkiye Klinikleri J Med Sci 2011;31:156-63. [Article in Turkish]

18. Innocent O., Thankgod OO, Sandra EO, Josiah IE. Correlation between body mass index and blood glucose levels among some Nigerian undergraduates. HOAJ Biology 2013;2:4. 19. TEMD Obezite, Lipid Metabolizması, Hipertansiyon Çalışma Grubu, Ankara, 2016: p20.

20. Pi-Sunyer FX. Short term medical benefits and adverse effects of weight loss. Ann Intern Med 1993;119:722-6.

21. Faheem M, Qureshi S, Ali J, Zahoor H, Abbas F, Gul A, et al. Does BMI affect cholesterol, sugar, and blood pressure in general population? J Ayub Med Coll Abbottabad 2010;22:74-7.

22. Kıdır V. [Cardiovascular and metabolic effects of vitamin D]. J Clin Exp Invest 2013;4:398-404. [Article in Turkish]

23. Oral O, Zusa A, Hasdemir SP, Nomikos G, Varol SR. Vitamin $\mathrm{D}$ and its metabolic functions. Int J Sci Culture Sports 2015;3(Special Issue 4):486-93.

24. Grønborg IM, Lundby IM, Mølgaard C, Jakobsen J, Ovesen L, Andersen R. Association of body fat and vitamin D status and the effect of body fat on the response to vitamin D supplementation in Pakistani immigrants in Denmark. Eur J Clin Nutr 2015;69:405-7.

25. Misra UK, Kalita J, Das A. Vitamin B12 deficiency neurological syndromes: a clinical MRI and electrodiagnostic study. Electromyogr Clin Neurophysiol 2003;43:57-64.

26. Wolters M, Ströhle A, Hahn A. Cobalamin. A critical vitamin in the elderly. Prev Med 2004;39:1256-66. 
27. Pennypacker LC, Allen RH, Kelly JP, Matthews LM, Grigsby J, Kaye K, et al. High prevalence of cobalamin deficiency in elderly outpatients. J Am Geriatr Soc 1992;40:1197-204.

28. Pfeiffer CM, Caudill SP, Gunter EW, Osterloh J, Sampson EJ. Biochemical indicators of B vitamin status in the US population after folic acid fortification: results from the National Health and Nutrition Examination Survey 1999-2000. Am J Clin Nutr 2005;82:442-50.

29. Metz J. A high prevalence of biochemical evidence of vitamin B12 or folate deficiency does not translate into a comparable prevalence of anemia. Food Nutr Bull 2008;29:S74-86.

30. Leal NA. B12 metabolisms in humans. Florida, University of Florida. 2004:1-156.

31. Herrmann W. The importance of hyperhomocysteinemia as a risk factor for diseases: an overview. Clin Chem Lab Med 2001;39:666-74.

32. Homocysteine Studies Collaboration, Homocysteine and risk of ischemic heart disease and stroke: a meta-analysis JAMA 2002;288;2015-22.

33. Martos R, Valle M, Morales R, Canete R, Gavilan MI, Sanchez-Margalet V. Hyperhomocysteinemia correlates with insulin resistance and low-grade systemic inflammation in obese prepubertal children. Metabolism 2006;55:72-7.

34. Güven A, Inanc F, Kilinc M, Ekerbicer H. Plasma homocysteine and lipoprotein (a) levels in Turkish patients with metabolic syndrome. Heart Vessels 2005;20;290-5.

35. Schnyder G, Roffi M, Flammer Y, Pin R, Hess OM. Effect of homocysteine-lowering therapy with folic acid, vitamin B12, and vitamin B6 on clinical outcome after percutaneous coronary intervention: the Swiss Heart Study: a randomized controlled trial. JAMA 2002;228:973-9.

36. Baltaci D, Deler MH, Turker Y, Ermis F. Evaluation of serum Vitamin B12 level and related nutritional status among apparently healthy obese female individuals. Niger J Clin Pract 2017;20:99105 .
37. Ho M, Halim JH, Gow ML, El-Haddad N, Marzulli T, Baur LA, et al. Vitamin B12 in obese adolescents with clinical features of insulin resistance. Nutrients 2014;6:5611-8.

38. Goyal R, Dhanuka S, Mehta V, Khasgiwale M, Shivhare R. To study the vitamin B12 status in morbidly obese patients. Int J Food Nutr Sci 2013;2:73-6.

39. Knight BA, Shields BM, Brook A. Lower circulating B12 is associated with higher obesity and insulin resistance during pregnancy in a non-diabetic white British population. PloS One 2015; 10:e.0135268.

40. Pinhas-Hamiel O, Doron-Panush N, Reichman B, NitzanKaluski D, Shalitin S, Geva-Lerner L. Obese children and adolescents: a risk group for low vitamin B12 concentration. Arch Pediatr Adolesc Med 2006;160:933-6.

41. Ho M, Halim JH, Gow ML, El-Haddad N, Marzulli T, Baur LA, et al. Vitamin B12 in obese adolescents with clinical features of insulin resistance. Nutrients 2014;6:5611-8.

42. Dick KJ, Nelson CP, Tsaprouni L, Sandling JK, Aïssi D, Wahl $\mathrm{S}$, et al. DNA methylation and body-mass index: a genome-wide analysis. Lancet 2014;383:1990-8.

43. Brasileiro RS, Escrivao MAMS, Taddei JAAC, D'Almeida V, Ancona-Lopez F, Carvalhaes JTA. Plasma total homocysteine in Brazilian overweight and non-overweight adolescents: a casecontrol study. Nutr Hosp 2005;20:313-9.

44. Reitman A, Friedrich I, Ben-Amotz A, Levy Y. Low plasma antioxidants and normal plasma B Vitamins and homocysteine in patients with severe obesity. Isr Med Assoc J 2002;4:590-3. 45. Abu-Samak M, Khuzaie R, Abu-Hasheesh M, Jaradeh N, Fawzi M. Relationship of Vitamin B12 defi ciency with overweight in male Jordanian youth. J Appl Sci 2008;8:3060-3. 46. Tungtrongchitr R, Pongpaew P, Tongboonchoo C, Vudhivai $\mathrm{N}$, Changbumrung $\mathrm{S}$, Tungtrongchitr $\mathrm{A}$, et al. Serum homocysteine, B12 and folic acid concentration in Thai overweight and obese subjects. Int J Vitam Nutr Res 2003;73:814. 